\title{
Mixed fruit wastes as a potential source for Bacteriocin Producing Lactic acid bacterium - Lactobacillus saniviri NKSS1 ${ }^{\dagger}$
}

\author{
Naresh Kumar K. 1, Murugan S. 2, Gobi Krishnan S. 2, Tha. Thayumanavan 1,3,* \\ 1 Department of Biotechnology, Dr. G.R. Damodaran College of Science, Coimbatore, Tamil Nadu, India \\ 2 Department of Biosciences, Karunya Institute of Technology and Sciences, Coimbatore, Tamil Nadu, India \\ 3 Department of Biotechnology, KIT-Kalaignarkarunanidhi Institute of Technology, Coimbatore, Tamil Nadu, India \\ * Correspondence: thayumanavan@yahoo.com; \\ $\dagger$ Presented at International e-Conference on Bioengineering for Health and Environment (ICBHE 2020)
}

Received: 5.07.2020; Revised: 10.07.2020; Accepted: 12.07.2020; Published: 15.07.2020

\begin{abstract}
Mixed fruit juices contain microflora on the surface of fruits during the harvest and postharvest practices. The presence of useful organisms like lactic acid bacteria from the mixed fruit wastes was explored in this study since these microbes use these wastes as a nutrient source for their growth. The lactic acid bacteria isolated using MRS medium was identified as Lactobacillus saniviri NKSS1 by 16s rRNA analysis. The bacteriocin produced by Lactobacillus saniviri NKSS1 showed inhibitory effect against the food pathogen (Listeria monocytogenes) and clinical pathogen (Acinetobacter baumannii). Optimization of bacteriocin production from Lactobacillus saniviri NKSS1 was achieved at $24 \mathrm{~h}$ of incubation, temperature at $35{ }^{\circ} \mathrm{C}$ with the initial medium $\mathrm{pH}$ of 6.5 . The carbon \& nitrogen sources like dextrose $(3 \% \mathrm{w} / \mathrm{v})$ and yeast extract $(0.75 \% \mathrm{w} / \mathrm{v})$ enhanced the production of bacteriocin in MRS medium. Antimicrobial activity was reduced in the partially purified bacteriocin when incubated at 95 ${ }^{\circ} \mathrm{C}$ for $2 \mathrm{~h}$ but it retained its activity in the $\mathrm{pH}$ range of 5.5 to 8.5 . Whereas, metals like CuSO 4 and $\mathrm{MgSO} 4$ at $(0.5 \% \mathrm{w} / \mathrm{v})$ interfered with the antagonistic activity of partially purified bacteriocin. Ionic detergents like SDS and CTAB partially decreased the antimicrobial activity, while other non-ionic detergents inhibited the antimicrobial activity completely. The molecular weight of partially purified bacteriocin from Lactobacillus saniviri NKSS1 was found to be $10.9 \mathrm{kDa}$. It can be concluded that bacteriocin of L. saniviri NKSS1 holds a promising potential for extension of shelf-life and improvement of microbiological safety in food industries.
\end{abstract}

Keywords: Mixed fruit juice wastes; bacteriocins; Lactobacillus saniviri; non-dairy based probiotics; lactic acid bacteria.

(C) 2020 by the authors. This article is an open-access article distributed under the terms and conditions of the Creative
Commons Attribution (CC BY) license (https://creativecommons.org/licenses/by/4.0/).

\section{Funding}

This research received no external funding.

\section{Acknowledgments}

This research has no acknowledgment.

\section{Conflicts of Interest}

The authors declare no conflict of interest. 